6) F. Weber, W. A. Fisher H. Engellrecht, Stahl. u. Eisen 74 1954, 1521

7) Kraft. Sullivan; Tipper Pro. Roy. Soc. A221 1954,114

8）岡崎登, 小岛公平, 中原益次郎：機栰学会 1950, 86
9）中川有三，类田倊：材料試鮕 5 1956，21

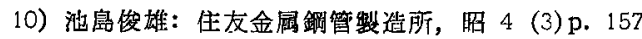

11) F. Seitz, adv, in Phys. 1195243

12) J. D. Eshelby, Pro. Roy. Soc. A. 621949 307

\title{
軸受鋼々塊の欠陌と地疪の関係*
}

(非金属介在物の研究一IV)

$$
\text { 河合 正 雄**・木 村弘*** }
$$

\section{THE RELATION BETWEEN THE DEFECTS OF INGOTS AND THE SAND MARKS OF BEARING STEEL}

\section{(The study of non-metallic inclusions-IV)}

\author{
Masao Kawai., Hiroshi Kimura
}

Synopsis:-

In the forth report, the authors studied the defects of the surface of ingot section, and - examined whether these defects had connection with sand marks of the steel rod.or not.

The results are briefly summarized as follows:

(1) Ingot defects are not changed by soaking, but analytical sands amount are changed.

(2) Generally, the part of chill crystals and columnar crystals of ingots have few defects, but free crystals on outside have many large defects, and there are many small defects in inner free crystals. These defects are the non-metallic inclusions. There are many cavities in the center of the ingot, of which length is long and diameter is small.

(3) The clearness of ingot is not alwaye proportional to the number of sand marks of the steel rod.

(4) There are some large non-metallic inclusions in the free crystal on outside of ingots and these defects are elongated in the course of rolling and grow up as sand marks of the steel rod.

\section{I. 緒言}

軸受鋼材に現われる地疵の原因は，第 1 報1 において 一部論及したごとく鋼塊に内藏されている欠俩である。 しかして鋼材の地症となる鋼塊における久陌として考え られるものは，非金属介在物，気泡，ピンホール，空孔 および強い局部傦析（かなり明瞭な境界および濃度差の ある偏析)などであり，をた鋼材の地㾋はすべての切削 面に大小，多少の差はあるけれどあ必ず現出する頻度の むのであるから，鋼塊における欠陷中で相当頻度の高い

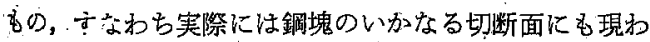

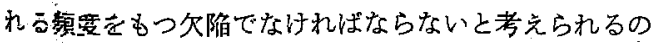
て 錩魄の一部分を切断研磨して顕微鏡検查，超音波試
験，清浄度などを調查して，鋼塊と地疵との閔係を求め た。

\section{II. 鋼塊切断面における欠陥の顕微鏡 的検査とサンド分析}

\section{（1）試料採取方法}

下注法による $250 \mathrm{~kg}$ 䡉受鋼塊の中心より縦に2つに

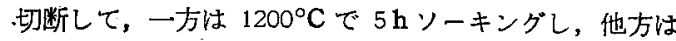
その儘の状態で Fig. 1 のごとくそれぞれ頭部，中部，

* 胎和 32 年 10 月本会講演大会にて発表

***大阪府立大学工学部教授 工博

**** 大阪府立大学工学部金属工学科 


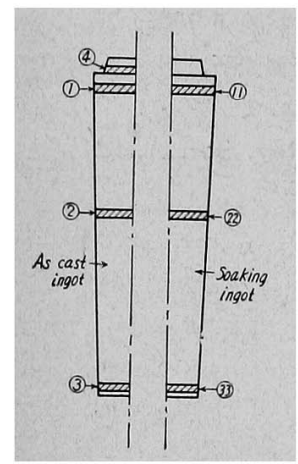

Fig. 1. Sampling method for the inspection of defects in 250 $\mathrm{kg}$ ingot.

速かに 100 倍または 600 倍で全面にわたり全欠陥につ

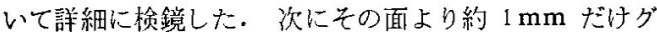
ラインダーミ゙落した面について，前[回と同様な检鏡する ことを 5 回操返した.すなおち試料(11), (22),(33), (1), (2), (3), (4)についておのおの5 面づウ，計 35 面について詳細に 検鏡したが、ソーキングした試料と銅塊その睢のものと は検鏡的には差異范認めず，すなわちソーキングによつ て銅塊の欠陷の形状は顥微鏡的には变化をしないことが 明らかとなつた。

$250 \mathrm{~kg}$ 鋼塊のチル晶部の厚さはほメ゙ 2〜3 mm であつ て，柱状晶部は約 $15 \mathrm{~mm}$ である。检鏡によると鋼塊の 欠陌は活とえどすべて非金属介佂物であつて,チル晶部, 柱状晶部には少く，牊も小さい。またこの実験ではチル 晶部，柱状晶部に気泡，ピシホール注見当らなかつた。

(この項ではとくに断りのない限り 35 被検面について またそれの平均的性質について述べる.)

Photo. 1 は鈰塊頭部側の外䧓（外より $2 \sim 3 \mathrm{~mm}$ の 距離の所）部に現われた，この箇所のものとしては非常 に大きな非金属介在物の一例である。

Photo. 1 に見られるごとく，このチル晶部附近の地 は美麗である。また非金属介在物の形はや〉角張つた形 であること，チル晶部附近でこの程度の大きさの非金属 介在物は本実験ではこれのみで他になかつたような発生 頻度の稀であること，およびこの介在物より内側の地は 美麗であることまた凝固速度の早いことなどより，この 非金属介在物注錈込みの際のマクレ込みがチル晶部附近 でそのまま㠜固したものであろうと考えられる。

次に鋼塊頭部側の中心部自由晶の始まる，すなわち外 より 20〜25 mm の距崔にある非金属介在物は Photo. 2 のごとく，その形はや〉大型で球形を呈し頻度も高く

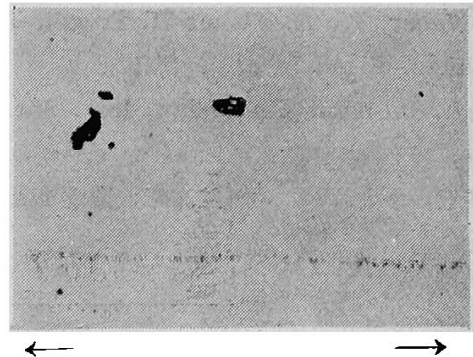

Outer side of the ingot Inner side of the ingot Photo. 1. Non metallic inclusion at the top of $250 \mathrm{~kg}$ ingot which distance is $2 \sim 3 \mathrm{~mm}$ from outer side. ( $30 \times 50 \mu$ large) $\times 100 \quad(2 / 3)$

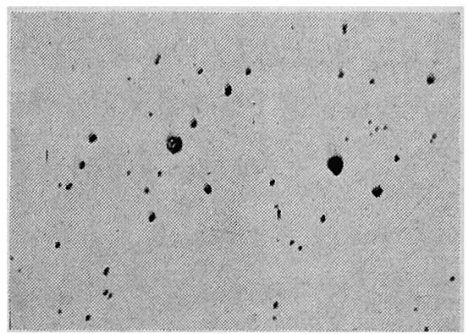

Photo. 2. Non metallic inclusions at the top of an ingot which is $20 \sim 25 \mathrm{~mm}$ distant from outer side. $(\sim 30 \times 30 \mu$ large $) \times 100(2 / 3)$

地はや〉污い。

この付近の非金属介在物は，その形の大きいこと，偶 然でない程度にかなりの高い頻度であること，球形をな すこと等より考えてこの䈯所で成長肥大したものであろ うと考えられる。すなわち内部自由晶の始をる付近は， 柱状晶部分におけるほどの温度勾配はないが，なおるる 程度の温度勾亚它持ち，またこの付近ては先行凝固した 柱状晶の末端を核として樹技状晶が発澾する。この樹技 状晶は比較的溶融点の高い，純隻の高いものであるが， 樹技状晶間にある溶湯は，それ之は反対に融点の比較的 に低い，不純なものをより多く偏析浱化しているので， したがつてこの溶湯中の非金属介在物は成長し 肥大す る.ゆえにその形状は他の简所のるのに比べて大きくか つ球形をなすものと考えられる.温度抅配の余りないか なり中心に近い箇所，すなわる鋼塊の頭部側で外側より 40 45 mm 付近（鋼塊頭部半径の約半分）の非 金属介 在物は，Photo. 3 のごとくや〉角張つた形でその大き さもや〉小さい，しかしてをたこの付近の欠陌も非金属 介在物のみであつて，鋼塊中心部におけるごとき空孔法 見当らない。 


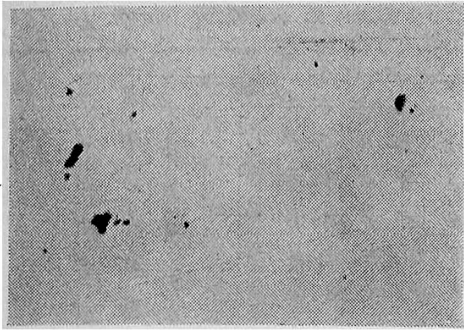

Photo. 3. Non-metallic inclusions at the top of ingot, which is $40 \sim 45 \mathrm{~mm}$ distant (about $1 / 2$ radius of ingot in this top side) from outer side. $(\sim 15 \times 50 \mu ; 25 \times 25 \mu$ large $)$ $\times 100(2 / 3)$

この外周より約 $1 / 2$ (鋼塊半径) 付近は温度忪配もか炋 り少ない状態で自由晶㠜固が咍まるがこの㭙は溶湯中

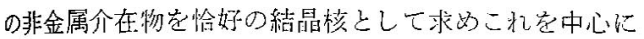

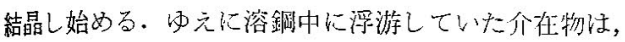
そのま凝固体の中にとじ込められて成長せず，末た偏 析した溶鋼中で㠜固過程に新しく生成された非金属介在 物㹸その成長時間が全体しして比軟的に短いた动にてい 形む小さいるの上考允られる。

それから中心にいたるにしたがつて非金属介在物の形 状む次第に球形加ら遠ざからた他々の形葆呈するむの上 なり，中心から 1/3(半经)の付近になると空孔がとこる ところに見られ，中心部には肉眼で見える程度の大きい 空孔がある.その一例を Photo. 4 に示す.

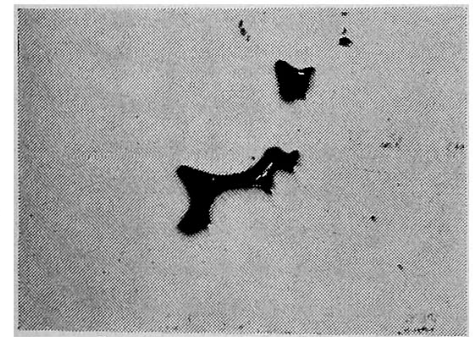

Photo. 4. Cavity at the top and center of the ingot. $(230 \times 30 \mu$ large $) \times 100(2 / 3)$

これは中心部湯不足による空孔であり，中心部二次パ イプの觹型である。

第目報2Iにおいてのベたごとく，押湯部の圧延材に

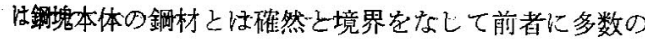
地碔が現われるので，鋳込状態の押湯部（試料番号(4)） の非金属介在物，気泡，空孔等の欠宿について調査した か；鋼塊本体部とは比較になら程度の非常に大きい非 金属介在物が全面に多数見られた，その一例を Photo. 5 亿示す.

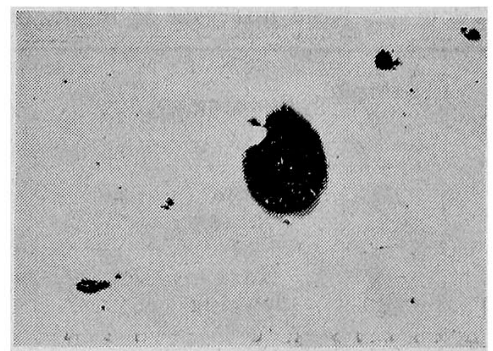

Photo. 5. Non-metallic inclusions at the shrinkage head near ingot itself. $(150 \times 130 \mu$ large $) \times 100(2 / 3)$

Photo. 5 の尔陥注非常に大きいために部の介在物 は脱落していたが，100 倍の顕微鏡下で的 $0.5 \sim 1 \mathrm{~mm}$ 厚みの，すぬわち $5 \sim 10 \mu$ 厚さの非金属介在物がこの欠 俩の外周に一様に付着していたので，この欠陷は最初に 哇非金属介在物が充実していたものであるう。

また浮板を使用せずに鋳込えだ下注鋼塊より死延した 鋼材には浮板を使用した場合のものより明かに地疪の多 いここが経験されている。ゆ光に鋼塊における両者の欠 陥家比較調查したが，浮板なしの鋸塊には柱状晶部に存 在する角張った形の非金属介在物が，浮板定使用した鋼 塊におけるよりもや〉多く，またその大きさむ大きい， その一例を Photo. 6 に示文.

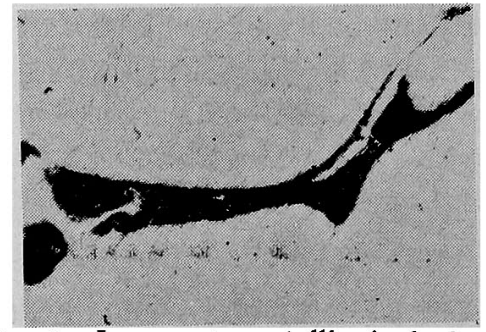

Photo. 6. Large non-metallic inclusions. It is inspected at the spot $4 \sim 5 \mathrm{~mm}$ distant from outside of the ingot in case of floating wood being not used.

$(\sim 100 \times 8 \mu$ large $) \times 100(2 / 3)$

これは柱状晶部にある非金属介在物としては異状に大 型で，写真において見られるごとく介在物の中に金属部 を挾み，その形状は鋳込みの際のスカムのマクレ込みの 急冷によるとじ込めと言つた感じを与えるものである.

次に鋼塊の上部，中部，底部の内外のサンド分析を試 料(11)，(22，(38)および(1)，(2)，(8)の外側部 \{すなわち1/10 $\times$ (鋼塊のその場所の直径) $\mathrm{mm}$ の外側部 $\}$ と, 中心部, \{才なわち $2 / 10 \times($ 鋼塊の之の場所の直径) $\mathrm{mm}$ の中心 部了:よりそれぞれ分析試料を採取し温硫酸法によりサン ド分析をした。その結果を Table 1 に示す. 
Table 1. Sand analysis of ingot, one is as-cast ingot, another is soaking ingot.

\begin{tabular}{|c|c|c|c|c|c|c|c|c|}
\hline \multirow{2}{*}{$\begin{array}{l}\text { Sample } \\
\text { position }\end{array}$} & \multirow{2}{*}{$\begin{array}{c}\text { Sample } \\
\text { No. }\end{array}$} & \multirow{2}{*}{ Soaking } & \multirow{2}{*}{$\begin{array}{l}\text { Total } \\
\text { sand } \%\end{array}$} & \multicolumn{5}{|c|}{ Chemical analysis of sand $\%$} \\
\hline & & & & $\mathrm{SiO}_{2}$ & $\mathrm{Al}_{2} \mathrm{O}_{3}$ & $\mathrm{FeO}$ & $\mathrm{MnO}$ & $\mathrm{Cr}_{2} \mathrm{O}_{8}$ \\
\hline $\begin{array}{l}\text { Top } \\
\text { Center }\end{array}$ & (1) & $\begin{array}{l}\text { None } \\
\text { Soaking }\end{array}$ & $\begin{array}{l}0.0099 \\
0.0092\end{array}$ & $\begin{array}{l}9 \cdot 90 \\
7 \cdot 25\end{array}$ & $\begin{array}{l}83 \cdot 20 \\
87 \cdot 50\end{array}$ & $\begin{array}{l}4 \cdot 32 \\
2 \cdot 90\end{array}$ & $\begin{array}{l}0.49 \\
0.14\end{array}$ & $\begin{array}{l}1 \cdot 98 \\
1 \cdot 02\end{array}$ \\
\hline $\begin{array}{l}\text { Top } \\
\text { Outside }\end{array}$ & (1) & $\begin{array}{l}\text { None } \\
\text { Soaking }\end{array}$ & $\begin{array}{l}0.0082 \\
0.0087\end{array}$ & $\begin{array}{r}13 \cdot 80 \\
9 \cdot 85\end{array}$ & $\begin{array}{l}82 \cdot 36 \\
83 \cdot 70\end{array}$ & $\begin{array}{l}1 \cdot 88 \\
2 \cdot 62\end{array}$ & $\begin{array}{l}0 \cdot 37 \\
0 \cdot 34\end{array}$ & $\begin{array}{l}1 \cdot 50 \\
0 \cdot 99\end{array}$ \\
\hline $\begin{array}{l}\text { Middle } \\
\text { Center }\end{array}$ & (2) & $\begin{array}{l}\text { None } \\
\text { Soaking }\end{array}$ & $\begin{array}{l}0.0138 \\
0.0102\end{array}$ & $\begin{array}{r}8 \cdot 26 \\
11 \cdot 75\end{array}$ & $\begin{array}{l}85 \cdot 90 \\
85 \cdot 15\end{array}$ & $\begin{array}{l}3 \cdot 08 \\
1 \cdot 22\end{array}$ & $\begin{array}{l}0.38 \\
0.47\end{array}$ & $\begin{array}{l}2 \cdot 64 \\
1 \cdot 53\end{array}$ \\
\hline $\begin{array}{l}\text { Middle } \\
\text { Outside }\end{array}$ & (2) & $\begin{array}{l}\text { None } \\
\text { Soaking }\end{array}$ & $\begin{array}{l}0.0125 \\
0.0090\end{array}$ & $\begin{array}{r}12 \cdot 20 \\
7 \cdot 78\end{array}$ & $\begin{array}{l}82 \cdot 22 \\
88 \cdot 90\end{array}$ & $\begin{array}{l}3 \cdot 57 \\
1 \cdot 00\end{array}$ & $\begin{array}{l}0.65 \\
0.89\end{array}$ & $\begin{array}{l}1 \cdot 38 \\
0 \cdot 45\end{array}$ \\
\hline $\begin{array}{l}\text { Bottom } \\
\text { Center }\end{array}$ & $(3)$ & $\begin{array}{l}\text { None } \\
\text { Soaking }\end{array}$ & $\begin{array}{l}0.0108 \\
0.0095\end{array}$ & $\begin{array}{r}11 \cdot 10 \\
4 \cdot 71\end{array}$ & $\begin{array}{l}85 \cdot 95 \\
91 \cdot 00\end{array}$ & $\begin{array}{l}1 \cdot 11 \\
2 \cdot 94\end{array}$ & $\begin{array}{l}0.40 \\
0.94\end{array}$ & $\begin{array}{l}1 \cdot 11 \\
1 \cdot 41\end{array}$ \\
\hline $\begin{array}{l}\text { Bottom } \\
\text { Outside }\end{array}$ & (3) & $\begin{array}{l}\text { None } \\
\text { Soaking }\end{array}$ & $\begin{array}{l}0.0152 \\
0.0109\end{array}$ & $\begin{array}{l}30 \cdot 52 \\
11 \cdot 70\end{array}$ & $\begin{array}{l}66 \cdot 70 \\
84 \cdot 50\end{array}$ & $\begin{array}{l}1 \cdot 14 \\
2 \cdot 39\end{array}$ & $\begin{array}{l}0.31 \\
0.65\end{array}$ & $\begin{array}{l}0.61 \\
1.43\end{array}$ \\
\hline
\end{tabular}

ソーキングしたものとしないものとの全サンド量を比 較すると頭部外側（Table 1 試料位置上より 2 目）を 除いてその他はすべてソーキングしたものほど少ない。 サンド組成の中た $\mathrm{SiO}_{2}$ は中部中心（Table 1 試料位置 上から 3 目) 以外のものはソーキングしないものつ方 が高い\%示し， $\mathrm{Al}_{2} \mathrm{O}_{3}$ は中部中心のもの以外はンーキ ングしないものつ方が低い\%である。

以上のごとくソーキングによるサンド量およびその組 成の变化の忙方はほづ一定の傾向を示している。ソーキ ングしたがつて一般に加熱により非金属介在物は多少变 化するけれども，これは地疵の原因として考えた非金属 介在物に重大なる変化をもたらすものとは考えられな w.

\section{III. 鋼塊の超音波試験とヘール仕上げした 鋼塊表面の検査}

$250 \mathrm{~kg}$ 下注軸受鋼塊の押湯部を切り取つて鋼塊本体を

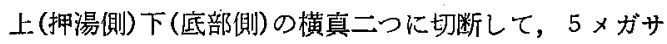
イクルの超音被で縦方向にそれぞれ中心部と外周部を検 查した結果, 押湯側の中心部は欠陌が多く底面反射が現 われないしかるにこの外周部の波形は底面反射のみが 現われその他に被形のみだれがないまた底部側の中心 部は波形のみだれがかなり多くあるが，底面反射もわか る程度であり，押湯側のものに比べると欠陥波は少いが なお多くの欠陥のあることが認められる。この底部側外 周部は欠陥波の現われないるのであることは前者外周部 と同様である: すなわち超音波試験によると $250 \mathrm{~kg}$ 鋼 塊の中心部には多数の欠陌一一前述 (I) の顕微鏡試験
とこの超望波試䮖とよりこの久陥は鋼䰠の空孔と見做さ

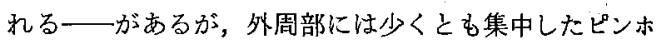
ール，気泡はない。しかして中心部の欠陌（空孔）は頭 部押湯側に到る程多くなつている。

鋼塊 $(250 \mathrm{~kg}, 150 \mathrm{~kg})$ の外周部のピンホールを調査す るために約半年間の溶解について下注䤻込定盤位置が注 入管から最も近い鋼塊と，最も遠いものそれでれ1本う

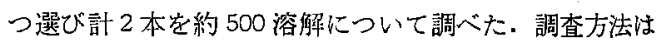
鋼塊を片面で約 $4 \mathrm{~mm}$ すなわち直径で 7〜8 $\mathrm{mm}$ 皮削 りした後へールバイトで削り面を仕上げ肉眼でピンホー ルを椧査したが，ピンホールのない鋼塊が多く，ピンホ ールの多いもので数個, 全体の平均で 1 鋼塊全表面につ き 1 個以下であつた。

超音波試験でも鎡塊の外周部には集中したピンホール のないことが明かである。ゆえに地瘷の主原因をピンホ ールとするにはその頻度が余りにも低い，また鋼塊の中 心部にはかなり大型の空孔が多数にある。しかるに厘延 鋼材の中心部には長い地疵がない（第 I 報3) II Table 1，Table 2 参照）ゆえに空孔は压延によつて死着し疵 とならないものと考えられるままたこのことから内面に 酸化物のない単純ピンホールは性着し趾とならないむの と考えてよい。

\section{IV. 鋼塊の清浄度と地疵との関係}

点算法により Fig. 1 の(1)(2(3)およ゙(4)の訆料の外周 部より $10 \mathrm{~mm}$ 間隔で非金属介在物の清浄度を求めた結 果を Fig. 2 に示す.

鋼塊の清浄度はいずれの部位のものも最外周が最も良 


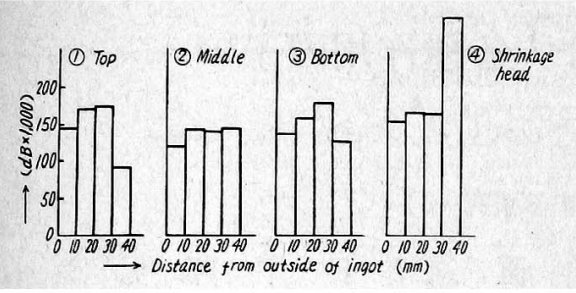

Fig. 2. Purity of the $250 \mathrm{~kg}$ ingot surface.

好で古り，外周より $30 \mathrm{~mm}$ に到る亡でのとこるでは灲 部に行くほど清浄度が多少䭴くなつているが，い方じる いい差がない，一般に地症梌查において地趾成績は鋼材

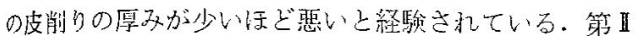

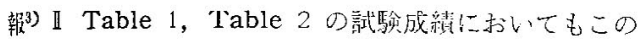

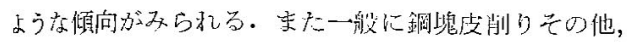

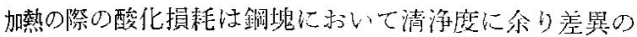

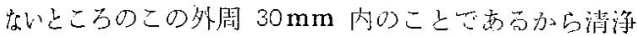
度の良否は地泟の原因に刘し，第一義的な意味をもつてい ないととに押湯部（試料(4)）の清浄度は他のものに比 ベて少し悪い程度であるにもかからずそれ等の圤壮数 の間には確然たる差珙がある。（第吕報》II Fig. 1 参 照)以上のことから地佌の原因となる非食属介在物はそ の数，総量等が余り問题でなくしてその個々の大きさが 問題であり，压延に際してその延び方をた引きち学れる 時はその配列方法が問題で西ると解される。

\section{V. 非金属介在物の体積と地疵の 長さとの関係}

鋼材の榉渐面（压延方向に直伤の断面）に抢け吕非金

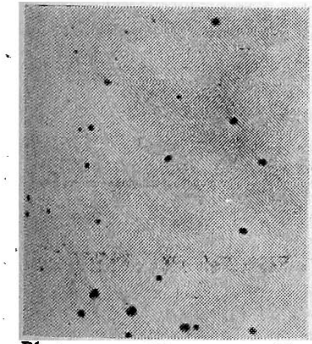

Photo. 7. Non-metallic inclusions at longitudinal section of bar. $\times 100 \quad(2 / 3)$ 属介在物は寸べて Photo. 7 の゙々くほぶ円形童呈し てい:

したがつて压恶により変 形した非金属介在物の形は 大体に赫いて連続をた峙不 速続の円筒形と見做しても 上い，今镃塊の球形非金属 介在物が压延により変形し て円筒形となり，これが地， 疵になるものと仮定する。

$(100 \mu)$ であるといわれるが，第吕報2，IV Photo. 3の

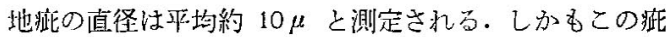
は切削面その售の状態で肉眼で見出されたものである。 (切削の際に第啝報2) N Photo. 1 のごとくに疵の中に ある非金属介在物が流狆出てその巾厇く見せるために 実際の呲中のせまいものも肉腿で見えるようになる)。 また鋼塊の内部自由晶部外側には Photo. 2 のごとく直 径 $30 \mu$ 位の非金属介在物が多数ある. こ机が今直径 10 $\mu$ の円筒形の地疵になつたものと仮定する

(非金属介在物の体積) $=4 / 3 \cdot \pi \cdot(15)^{3}$

(地些の体積) $=\pi \cdot(5)^{2} \cdot l \mu^{3} \quad l \cdot \cdots$ 地疵の長さ $(\mu)$

$$
\therefore l=180 \mu=0.18 \mathrm{~mm}
$$

寸なわち鋼塊の内部自由晶の外側に多数見受けられる 非金属介在物は $0.18 \mathrm{~mm}$ の地疪に変化することができ る.この場合の里延比は約6でありそれ以上にのびる㭙 は巾が狭くなりこの地症は肉眼で見えなくなることもあ り得る。換言すると地站が消える。

（実際には切消条件により介在物の流机方がことなるた わに本当の疵の巾のみでは云々できながいこの計算は一 忍の目安を与えるものである.)

\section{VI. 結 言}

以上を要約す机ば次のごとし。

（1）ソーキングによつて鋼塊の欠栺は変形しない。 しがしながらンーキングすると分析サンド量は变化す ๖.

（2）一般に銅塊のチル晶部・柱状晶部恃欠陥が少く， 外側白由昆部に大きい欠宿があり，内側自由晶部の欠㫟 は形が小さい。しかしてそ机らの陌はすべて非金属介 在物である、また細長い鋼塊の中心部には空孔が多数あ る.

（3）鋼塊の清浄度と鋼材の地㾟とは必ずじも比例し ない.

（4）鋼塊の外側に近い自由晶部に普通にある非金属 介在物は压延により十分地㾃となり得る大ささである。

(昭. 33 - 3 月寄稿)

文献

1) 河合正雄, 木村 弘：銑上銅，44（1958） No. 6

2) 河合正雄, 木村 弘: 鉄と鎆, 44 -(1958) No.7

3）河合正雄，木村. 弘：鉄と鋼，44（1958） No. 8

一般に正常な肉眼の分解能は $25 \mathrm{~cm}$ の距離で約 $0.1 \mathrm{~mm}$ 